\title{
Multi-criteria analysis of the construction technologies in the aspect of sustainable development
}

\author{
Magdalena Gicala ${ }^{1, *}$, and Anna Sobotka ${ }^{1}$ \\ ${ }^{1}$ AGH University of Science and Technology, Faculty of Mining and Geoengineering, \\ al. Mickiewicza 30, 30-059 Cracow, Poland
}

\begin{abstract}
The complexity of sustainability complicates the design work and requires the implementation of Integrated Life Cycle Design. Due to the need of balance between environmental, social and economic aspects and the multitude of analysis indicators, the assessment of existing buildings is a multi-criteria problem too. The aim of the study is to compare three construction technologies - two traditional solutions and an innovative technology - in the aspect of sustainable development. The assessment was limited to the building envelope materials and included in entirety of 13 environmental, social and economic indicators, characteristic for the first stage of building life cycle. The absence of explicit dominance of one technology over another in terms of these factors was a starting point for the multi-criteria analysis. Based on the comparison of given technologies by WSM and TOPSIS methods, the multi-criteria analysis was carried out and the most advantageous technology was indicated. The results allow for an indirect selection of building materials to fulfil the sustainability requirements for the building.
\end{abstract}

\section{Introduction}

Since the United Nations Conference on Environment and Development (UNCED) in Rio de Janeiro, called the Earth Summit (1992), attention has been paid to the issue of sustainable development and to the implementation of its elements in various sectors of the economy. It is aimed at meeting the needs of the present without compromising the ability of future generations by harmonizing environmental, social and economic activities. These assumptions are reflected in construction industry too. The research undertaken in this area have different scopes and cover specific aspects of sustainability [1], selected life cycle stages [2], impacts or parts of a building, especially building materials [3]. However, the dynamic socio-economic development and changes in the construction industry require the update of research, correction of the assessment factors and the analysis of new technologies. The results obtained in this way form a basis to determine the development potential of selected technologies or indicating their shortcomings in the face of dynamic changes in construction industry.

\footnotetext{
*Corresponding author: mgicala@agh.edu.pl
} 


\section{Research methodology}

The purpose of the study was to rank selected construction technologies (T1-T3) from the one that best satisfies sustainability requirements to the worst one. The assessment was limited to the building envelope materials and included in entirety of 13 environmental, social and economic indicators, characteristic for the first stage of building life cycle. The information contained in Environmental Product Declarations, catalogues and price lists of construction product manufacturers, and the data obtained from calculations were used in the analysis. The studies were carried out according to the currently applicable standards concerning the issue of sustainable building [4,5]. Due to the complexity of the sustainability issue, the multi-criteria approach was proposed in the second part, as it would allow considering simultaneous influence of various factors on the solution priority. The technologies were analysed using the WSM (Weighted Sum Method) and TOPSIS method (The Technique for Order of Preference by Similarity to Ideal Solution). The most advantageous technology was indicated on the basis of the obtained results.

\subsection{The subject of the analysis}

The subject of the analysis was a single-family one-storey residential building, located in Poland, made with the technology of self-supporting building development systems based on foamed polystyrene (T1) with a usable area of $110.75 \mathrm{~m}^{2}$. For the purpose of the study, alternative conventional solutions such as: technology of timber frame building (T2) and technology using ceramic construction materials (T3) were considered. Comparison was made on the basis of building material impacts per $1 \mathrm{~m}^{2}$.

\subsection{Environmental aspect analysis}

Environmental analysis covered 11 indicators selected from those proposed by the standard EN 15643. The values of the indicators were determined on the basis of Environmental Product Declarations (EPD) and the results of material consumption analysis for building envelope. The calculation was carried out using the following formula (1):

$$
P_{t e}=\sum_{j=1}^{m} k_{e j} m_{j}
$$

where:

$k_{e j} \quad$ environmental impact indicator for unit volume of the $\mathrm{j}^{\text {th }}$ material in $\mathrm{e}^{\text {th }}$ environmental impact category,

$m_{j} \quad$ amount of the $\mathrm{j}^{\text {th }}$ material in $1 \mathrm{~m}^{2}$ of partition area,

$P_{t e} \quad$ environmental impact of materials in $1 \mathrm{~m}^{2}$ of the partition made using the $t^{\text {th }}$ technology in $e^{\text {th }}$ category.

The values of the indicators were referred to the unit of building usable area, and the $S_{t e}$ values were obtained. The Ecopoint unit [6,7] determined on the basis of relation (2) was used to rank the analysed technologies:

$$
E_{p}=\sum_{e=1}^{n_{e}}\left(\frac{S_{t e}}{R_{e}} \times w_{e}\right)
$$


where:

$e \quad$ number of environmental impact category, $e=1,2, \ldots, n_{e}, n_{e}=11$,

$w_{e} \quad$ weight of $\mathrm{e}^{\text {th }}$ environmental impact category,

$R_{e} \quad$ reference value for $\mathrm{e}^{\text {th }}$ category of environmental impacts (annual impacts of 1 European citizen),

$S_{t e} \quad$ characterized indicator describing $\mathrm{e}^{\text {th }}$ category of environmental impacts for $\mathrm{t}^{\text {th }}$ technology (per $\left.1 \mathrm{~m}^{2}\right)$.

The reference values and weights of the environmental indicators were taken according to $[6,8-10]$ and shown in Table 1 .

Table 1. Reference values $\left(R_{e}\right)$ per person per year and weights $\left(W_{e}\right)$ of environmental indicators.

\begin{tabular}{|c|c|c|c|}
\hline Indicator (Abbreviation of indicator) & Units & $\boldsymbol{R}_{\boldsymbol{e}}$ & $\boldsymbol{W}_{\boldsymbol{e}}[\mathbf{\%}]$ \\
\hline Global warming potential (GWP) & $\mathrm{kgCO}_{2} \mathrm{eq}$ & 12,300 & 24.1 \\
\hline Net use of fresh water (FW) & $\mathrm{m}^{3}$ & 377 & 15.2 \\
\hline Depletion potential of the stratospheric ozone layer (ODP) & $\mathrm{kgCFC}_{11}$ eq. & 0.22 & 13.5 \\
\hline Acidification potential of land and water (AP) & $\mathrm{kgSO}_{2}$ eq. & 71.2 & 8.4 \\
\hline Eutrophication potential (EP) & $\mathrm{kg}\left(\mathrm{PO}_{4}\right)^{3-}$ eq. & 32.5 & 8.2 \\
\hline Radioactive waste disposed (RWD) & $\mathrm{kg}$ & 3.91 & 7.0 \\
\hline Abiotic Resources Depletion Potential for elements (ADPE) & $\mathrm{kg} \mathrm{Sb}$ eq. & 39.1 & 6.6 \\
\hline Photochemical ozone creation potential (POCP) & $\mathrm{kg} \mathrm{Ethene} \mathrm{eq.}$ & 21.5 & 5.8 \\
\hline Hazardous waste disposed (HWD) & $\mathrm{kg}$ & 187.4 & 5.0 \\
\hline Abiotic Resources Depletion Potential of fossil fuels (ADPF) & $\mathrm{MJ}$ & 273,000 & 4.0 \\
\hline Non-hazardous waste disposed (NHWD) & $\mathrm{kg}$ & 3,750 & 2.1 \\
\hline
\end{tabular}

\subsection{Social aspect analysis}

The social aspect analysis was based on one of the categories indicated by the EN 15643-3: health and comfort, taking into account thermal characteristics. This criterion was represented by the heat transfer coefficient of the external wall, its value was calculated on the basis of the relation:

$$
U=\sum_{j=1}^{m}\left(d_{j} / \lambda_{j}\right)
$$

where:

$\begin{array}{ll}U & \text { heat transfer coefficient of external wall, } W / m^{2} K, \\ d_{j} & \text { thickness of } \mathrm{j}^{\text {th }} \text { material of external wall layer, } m, \\ \lambda_{j} & \text { thermal conductivity of } \mathrm{j}^{\text {th }} \text { material of external wall layer, } \mathrm{W} / \mathrm{mK} .\end{array}$

\subsection{Economic aspect analysis}

According to the convention and scope of the research, the prices of building envelopes materials per usable area unit were assumed representative for the assessment and comparison of the technologies. The prices were calculated on the basis of data contained in the catalogues of material manufacturers. Moreover, using the formula (4), relative increase in prices for the technologies was determined, as compared to the lowest price:

$$
\delta_{c}=\left[\left(c_{t}-c_{\min }\right) / c_{\min }\right] \times 100 \%
$$


where:
$c_{t} \quad$ price of materials per $1 \mathrm{~m}^{2}$ of usable area for $\mathrm{t}^{\text {th }}$ technology [PLN],
$c_{\text {min }}$ the lowest estimated price [PLN].

\subsection{Multi-criteria analysis}

According to the general principles of building sustainability [5], all 3 aspects of sustainable development are necessary elements in the systemic approach. Therefore, it is required to consider simultaneous influence of environmental, social and economic impacts. A multi-criteria analysis based on WSM and TOPSIS methods is applicable in this issue, in order to minimize the subjectivism and assurance of result reliability. Environmental, social and economic aspects (analysis criteria) were represented by Ecopoint (Ep), heat transfer coefficient (U) and price of material (Pm), respectively.

WSM: The Weighted Sum Method is a mathematical method to optimize solutions and to support the decision-making process while required to consider various factors simultaneously. The values of synthetic indicators proper for each technology were determined using the formula [11]:

$$
J_{t}=\sum_{i=1}^{n}\left(x_{t i}^{\prime} / x_{\text {imax }}{ }^{\prime}\right) \times W_{i}
$$

where:

$J_{t} \quad$ value of synthetic indicator for $\mathrm{t}^{\text {th }}$ technology,

$W_{i} \quad$ weight of $\mathrm{i}^{\text {th }}$ sustainability aspect (criteria),

$i \quad$ sustainability aspect, $i=\{1,2,3\}$,

$x_{t i}$ the original values of Ep, $\mathrm{U}$ and $\mathrm{Pm}$ for each technology,

$x_{t i}{ }^{\prime}=1 / x_{t i}$

$x_{i \max }{ }^{\prime}$ maximum value of the $\mathrm{i}^{\text {th }}$ criterion's measures after maximization.

TOPSIS: The essence of this method is to find among the analysed solutions the one, closest to the ideal solution to satisfy the required criteria as much as possible, at the same time most distant from the anti-ideal solution. This method is currently widely used in relation to the sustainable development and sustainable building as well. The search for the most advantageous solution is carried out in several stages, described in detail e.g. in [13]. Relative closeness to an ideal solution has been determined using the formula [14]:

$$
d_{t}=d_{t}^{-} /\left(d_{t}^{+}+d_{t}^{-}\right)
$$

where:

$d_{t}^{+} \quad$ distance of the $\mathrm{t}^{\text {th }}$ technology from the ideal solution,
$d_{t}^{-} \quad$ distance of the $\mathrm{t}^{\text {th }}$ technology from the anti-ideal solution.

The standardisation procedure for $\mathrm{i}^{\mathrm{th}}$ analysis criterion (sustainability aspect) measure of the $\mathrm{t}^{\text {th }}$ technology was carried out according to the formula:

$$
z_{t i}=x_{t i} / \sqrt{\sum_{t=1}^{T} x_{t i}^{2}}
$$


where:

$x_{t i}$ - original $\mathrm{i}^{\text {th }}$ criterion measure of the $\mathrm{t}^{\text {th }}$ technology.

In both - WSM and TOPSIS method - the equivalence of the environmental, social and economic aspects, according to the idea of sustainable development, was assumed. Thus the weights $W_{i}$ for sustainability aspects, being analysis criteria, are equal $\left(W_{i}=1 / 3\right)$.

\section{Research results}

\subsection{Environmental aspect analysis}

The environmental indicators chosen in the analysis are dis-stimulants. Therefore, there is an attempt to find a technology, which would reach lowest Ecopoints value and thus would have the most advantageous environmental profile. Fig. 1 shows research results in form of a cumulative diagrams of environmental indicators and Ecopoint values for each technology.

The most advantageous result $\left(\mathrm{E}_{\mathrm{p}}=0.108\right)$ is achieved by the timber frame technology. In a large extent this is caused by the impact of $\mathrm{T} 2$ technology on global warming. Timber is a renewable resource, forest vegetation contributes to $\mathrm{CO}_{2}$ reduction in the atmosphere. Other indicators (apart from FW) remain also at a relatively low level. The worst result is achieved by the $\mathrm{T} 1$ technology $\left(\mathrm{E}_{\mathrm{p}}=0.457\right)$. The reasons are considerable impact on global warming and high photochemical ozone creation potential.

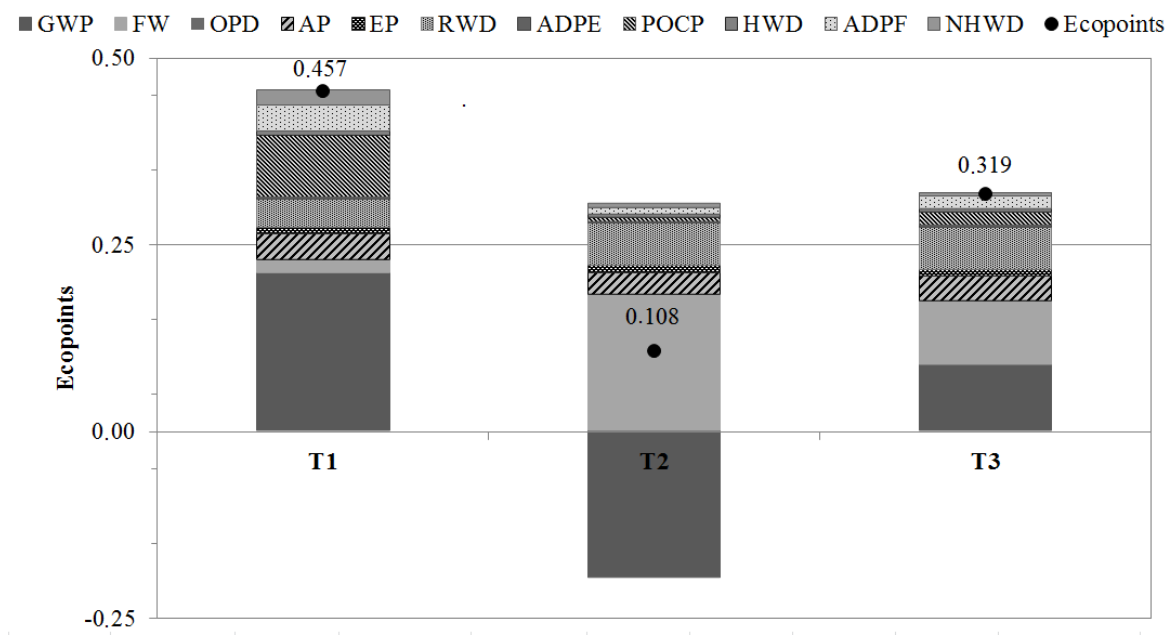

Fig.1. Ecopoints value for analysed technologies (T1, T2, T3).

\subsection{Social aspect analysis}

The tables 2-4 illustrate arrangement of layers, heat transfer coefficient values and thicknesses of external walls for T1-T3 technologies. 
Table 2. External wall layers and heat transfer coefficient for technology T1.

\begin{tabular}{|c|c|c|c|}
\hline Material of layer & $\lambda(\mathbf{W} / \mathbf{m K})$ & Thickness (m) & $\mathbf{U}\left(\mathbf{W} / \mathbf{m}^{2} \mathbf{K}\right)$ \\
\hline Plasterboard & 0.25 & 0.013 & \multirow{5}{*}{0.11} \\
\hline Adhesive mass with reinforced lattice & 0.8 & 0.005 & \\
\hline Self-supporting polystyrene profiles & 0.034 & 0.02 & \\
\hline Cement-lime plaster & 0.083 & 0.02 & \\
\hline \multicolumn{2}{|c|}{ Wall thickness $(\mathrm{m})$} & 0.338 & \\
\hline
\end{tabular}

Table 3. External wall layers and heat transfer coefficient for technology T2.

\begin{tabular}{|c|c|c|c|}
\hline Material of layer & $\lambda(\mathbf{W} / \mathrm{mK})$ & Thickness (m) & $\mathbf{U}\left(\mathbf{W} / \mathbf{m}^{2} \mathbf{K}\right)$ \\
\hline Plasterboard & 0.25 & 0.013 & \multirow{8}{*}{0.21} \\
\hline Non ventilated air gap & - & 0.025 & \\
\hline Vapour- insulation foil & 0.18 & 0.002 & \\
\hline Mineral wool & 0.034 & 0.16 & \\
\hline OSB & 0.13 & 0.015 & \\
\hline Wind-insulation foil & 0.18 & 0.002 & \\
\hline Wooden facade & - & - & \\
\hline \multicolumn{2}{|c|}{ Wall thickness (m) } & 0.217 & \\
\hline
\end{tabular}

Table 4. External wall layers and heat transfer coefficient for technology T3

\begin{tabular}{|l|c|c|c|}
\hline \multicolumn{1}{|c|}{ Material of layer } & $\boldsymbol{\lambda} \mathbf{( W / m K )}$ & Thickness $(\mathbf{m})$ & $\mathbf{U}\left(\mathbf{W} / \mathbf{m}^{\mathbf{2}} \mathbf{K}\right)$ \\
\hline Cement-lime plaster & 0.83 & 0.01 & \\
\cline { 1 - 2 } Hollow brick & 0.39 & 0.29 & \multirow{2}{*}{0.23} \\
\cline { 1 - 2 } Polystyrene foam & 0.034 & 0.12 & \\
\cline { 1 - 2 } Cement-lime plaster & 0.83 & 0.015 & \\
\cline { 1 - 2 } \multicolumn{2}{|r|}{ Wall thickness (m) } & 0.435 & \\
\hline
\end{tabular}

Note: $\lambda=$ thermal conductivity of material; $U=$ heat transfer coefficient .

The coefficient $U$ in technology T2 is close to the value for technology T3 (wall being twice thinner). The lowest value of coefficient $U$ is observed for technology T1, which results from considerable thickness of the main material $(30-74 \mathrm{~cm})$ and low $\lambda$ value of this material.

\subsection{Economic aspect analysis}

In order to assess and compare the technologies, the prices of building envelopes materials were calculated per $1 \mathrm{~m}^{2}$ of usable area and the results are shown in Table 5.

Table 5. Prices of building materials of external walls and roofs in analyzed technologies, PLN.

\begin{tabular}{|l|c|c|c|}
\hline \multicolumn{1}{|c|}{ Price of materials $^{\mathbf{a}}$} & Technology T1 & Technology T2 & Technology T3 \\
\hline Envelope building materials, PLN & $41,699.18$ & $56,655.23$ & $53,595.76$ \\
\hline Per $1 \mathrm{~m}^{2}$ of usable area (Pm), PLN/m ${ }^{2}$ & 376.52 & 511.56 & 483.93 \\
\hline Relative increase of prices, \% & - & 35.9 & 28.5 \\
\hline
\end{tabular}

${ }^{a}$ Based on catalogs of materials manufacturers.

The technology T1 detects the lowest price of materials per usable area unit. Thus, the price of materials used in technology T3 is almost $29 \%$ higher. The highest price of materials is observed for technology T2. Erection of a building in this technology requires that properly selected, assorted and processed timber is used, what generates high material costs. The price is almost $36 \%$ higher than the lowest price, assessed and shown in Table 5. 


\subsection{Multi-criteria analysis}

WSM: The original and normalized measures of criteria (sustainable aspects) and their weights are shown in Table 6.

Table 6. The values of criteria measures (original $-x_{t i}$, normalized $-z_{t i}$ ) and synthetic indicator.

\begin{tabular}{|c|c|c|c|c|c|c|c|}
\hline \multirow{2}{*}{ Technology } & \multicolumn{2}{|c|}{ Ep } & \multicolumn{2}{|c|}{$\mathbf{U}$} & \multicolumn{2}{|c|}{ Pm } & \multirow{2}{*}{$\boldsymbol{J}_{\boldsymbol{t}}$} \\
\cline { 2 - 7 } & $\boldsymbol{x}_{\boldsymbol{t} \boldsymbol{i}}$ & $\boldsymbol{z}_{\boldsymbol{t} \boldsymbol{i}}$ & $\boldsymbol{x}_{\boldsymbol{t} \boldsymbol{i}}$ & $\boldsymbol{z}_{\boldsymbol{t} \boldsymbol{i}}$ & $\boldsymbol{x}_{\boldsymbol{t} \boldsymbol{i}}$ & $\boldsymbol{z}_{\boldsymbol{t} \boldsymbol{i}}$ & \\
\hline $\mathrm{T} 1$ & 0.457 & 0.236 & 0.11 & 1.000 & 376.52 & 1.000 & 0.745 \\
\hline $\mathrm{T} 2$ & 0.108 & 1.000 & 0.21 & 0.547 & 511.56 & 0.736 & 0.761 \\
\hline $\mathrm{T} 3$ & 0.319 & 0.338 & 0.23 & 0.483 & 483.93 & 0.778 & 0.533 \\
\hline Weight & \multicolumn{2}{|c|}{$33.3 \%$} & \multicolumn{2}{|c|}{$33.3 \%$} & \multicolumn{2}{|c|}{$33.3 \%$} & \\
\hline
\end{tabular}

The most advantageous technology shows the highest value of synthetic indicator $\left(J_{t}\right)$. It is observed that technology $\mathrm{T} 2$ is the prevailing one due to the significant predominance of this solution with reference to the environmental aspect (Table 6). Technology T1 is the second in ranking as a result of low environmental efficiency characterised by the Ecopoint rate value and high social and economic performance

TOPSIS: Comparisons shown in Table 7 were obtained as a result of applying the TOPSIS method to solve the problem of selecting the technology that would best satisfy all of the main criteria.

Table 7. Results of TOPSIS method- distances of technologies from ideal and anti-ideal solutions.

\begin{tabular}{|c|c|c|c|}
\hline \multirow{2}{*}{ Technology } & \multicolumn{3}{|c|}{ Results of TOPSIS method } \\
\cline { 2 - 4 } & $\mathbf{d}_{\mathbf{t}}^{+}$ & $\mathbf{d}_{\mathbf{t}}{ }^{-}$ & $\mathbf{d}_{\mathbf{t}}$ \\
\hline $\mathrm{T} 1$ & 0.2049 & 0.1339 & 0.395 \\
\hline $\mathrm{T} 2$ & 0.1096 & 0.2067 & 0.653 \\
\hline $\mathrm{T} 3$ & 0.1793 & 0.0817 & 0.313 \\
\hline
\end{tabular}

Therefore there is an attempt to find a technology which would reach highest value $d_{t}$ indicating relative closeness to the ideal solution. Technology T2 is the most distant from anti-ideal solution (highest value of $d_{t}^{-}$) and at the same time closest to the ideal solution (lowest value of $d_{t}^{+}$). As regards the other two technologies T1 is closer to the ideal. In case of the TOPSIS method, the position of a given technology is determined by the values of the criteria measures for other technologies.

\section{Conclusions}

In the study the authors have proved usefulness of the multi-criteria analysis in selecting a technology, which would most effectively fulfil the sustainable building assumptions. Indirectly this analysis simplifies the materials selection in the process of integrated design and evaluation of innovative technologies due to the sustainable development principles. Following the entries in the standard EN 15643 and studies of other authors it was proposed to apply 13 assessment indicators from the environmental, social and economic groups to the three building construction technologies. The ranking process was carried out using two methods of multi-criteria analysis - WSM and TOPSIS. The completed research proves that the timber frames technology is the most advantageous among all considered in the analysis, what is largely the result of the environmental efficiency. The technology of selfsupporting building development systems based on foamed polystyrene is in the second place, due to the most advantageous social and economic profile and simultaneously very 
low environmental performance. It should be emphasised that the currently promoted issue of sustainable development in construction industry is still not adequately popularised among users of single-family residential buildings, hence it should be expected that the economic and social aspects will be more important for the decision makers (users, inhabitants) than the environmental ones. Considering this assumption and the obtained research results, it is found that new and only recently being developed technologies are close to optimal in given conditions. It is necessary to carry out further studies, taking into account other stages of the building life cycle and adding to the analyses other important criteria, particularly social and economic. Relations between research methods and results are also found, different rankings are anticipated, while other methods will be used.

\section{References}

1. A. Karatas, K. El-Rayes, Optimal trade-offs between social quality of life and Life-Cycle Cost in housing units, J. Constr. Eng. Manage. 140/12, 04014058 (2014)

2. Y. Kang et al., Comparison of preproject planning for green and conventional buildings, J. Constr. Eng. Manage., 139/11, 1-9 (2013)

3. O. Tatari, M. Kucukvar, Eco-efficiency of construction materials: Data envelopment analysis, J. Constr. Eng. Manage., 138/6, 733-741 (2012)

4. CEN (European Committee for Standardization), Sustainability of Construction Works Sustainability Assessment of Buildings Parts 1-4: General Framework, EN 15643-1 (20102012)

5. ISO (International Organization for Standardization), Sustainability in building constructionGeneral principles, ISO 15392 (2008)

6. J. Mundy, The Green Guide Explained. BRE Centre for Sustainable Products, $<$ http://www.bre.co.uk/filelibrary/greenguide/PDF/The-Green-GuideExplained_March2015.pdf>

7. V. Aymard, V. Botta-Genoulaz, Normalisation in life-cycle assessment: consequences of new European factors on decision-making, Proc., 6th International Conference on Information Systems, Logistics and Supply-chain ILS Conference 2016, Bordeaux, France (2017)

8. BRE (Building Research Establishment), Green Guide to Specification BRE Materials Industry Briefing Note $3 b$ : Normalisation, $<$ http://www.bre.co.uk/greenguide/files/NormalisationBriefingDocumentFinal.pdf $>$

9. OECD (Nuclear Energy Agency Organisation for Economic Co-Operation and Development), Radioactive Waste in Perspective, <https://www.oecd-nea.org/ndd/pubs/2010/6350-wasteperspective.pdf $>$

10. O. Abbe, L. Hamilton L, BRE Global Environmental Weighting for Construction Products using Selected Parameters from EN 15804, $<$ https://www.bre.co.uk/filelibrary/Materials/Environmental-weightings-15804_final.pdf $>$

11. I.Y. Kim, O.L. de Weck, Adaptive weighted sum method for multiobjective optimization: a new method for Pareto front generation, Struct. Multidiscipl. Optim., 31/2, 105-116 (2006)

12. J. Szwabowski, J. Deszcz, Elementy procesu decyzyjnego. In: Metody wielokryterialnej analizy porównawczej. Podstawy teoretyczne $i$ przykłady zastosowań $w$ budownictwie, 9-24 (Wydawnictwo Politechniki Śląskiej, Gliwice, 2001) [in Polish]

13. E.K. Zavadskas, Assessment of individual residential buildings external walls alternatives applying TOPSIS method, Proc., 9th International Conference on Modern Building Materials, Structures and Techniques, Vilnius, Lithuania, 1-3, $442-446$ (2008)

14. D. Mierzyńska, Wielowymiarowa analiza dobrobytu społeczno-ekonomicznego w Polsce [Multidimensional analysis of socio-economic well-being in Poland], Prace i Materiaty Wydziału Zarządzania Uniwersytetu Gdańskiego, 4, 8, $421-434$ (2011) [in Polish] 